\title{
CORRESPONDENCE
}

\section{Dating Error}

SIR, 一In the letter "Fission Track Dating of Archaeological Materials from Japan" (Nature, 230, 242 ; 1971), Nishimura states that ". . . several questions still remain unsolved". Indeed, several points remain unresolved to these readers.

Following the author's method of age calculation, the data in Table 1 for the glass ball, Hirono, Uji, Kyoto Pref., indicate an age of 180,000 years, not 1,480 years. Also, for the glaze on bowl, Isumi, Toki City, the data indicate an age of 47,000 years, not 400 years. In addition, there seems to have been an interesting but unknown factor used when rounding-off figures for several of the other ages.

When calculations of uranium concentrations are made from the data in Table 1, uranium concentrations of up to $0.7 \%$ in several slags and up to $10 \%$ in zircons were found. These values are unusually high and subject to suspicion.

Although the author did not specifically mention the method of counting, one can assume from the reported etching conditions that an optical microscope was used. To our knowledge and experience, it is impossible to resolve accurately and record fission tracks with densities of 10 million to nearly 1,000 million tracks $\mathrm{cm}^{-2}$, using an optical microscope.

Finally, we would like to emphasize that fission track dating of any material is possible only when $\mathrm{Cu} \cdot T>10$, where $\mathrm{Cu}=$ uranium concentration by weight $\%$ and $T=$ age in years (for minimum track density of ten tracks $\mathrm{cm}^{-2}$ ). That is, in order to date a material 1,000 years old, the uranium content of the material must exceed 100 p.p.m.

\section{Yours faithfully, \\ Gunther A. WAgner Michael REIMER}

Department of Geology,

University of Pennsylvania,

Philadelphia 19104

Dr Nishimura replies:

SIR,-I apologize for my mistakes, and comment as follows.
Application of the fission track method to archaeological remains:

(i) For the baked relics, zircon was separated from the baked relics using the standard separation methods: heavy liquids and isodynamic separator. A few hundred grains of zircon were collected from a sample. A part of these minerals (usually about ten to twenty grains) was irradiated by neutron flux, and etched by concentrated $\mathrm{P}_{2} \mathrm{O}_{5}$ at $450^{\circ}-480^{\circ} \mathrm{C}$ for the determination of suitable etching time. The other portion was etched on the basis of this test. The minerals containing one or more spontaneous fission tracks were selected under the microscope. The induced tracks in these minerals were counted after neutron bombardment.

(ii) For the glass, the glasses were mounted in a clear epoxy resin on a polymer slide and the mount was then ground and polished to expose the interior of the glass. A small part of this glass was irradiated by neutron flux and was etched by $46 \% \mathrm{HF}$ at $25^{\circ} \mathrm{C}$ for the determination of suitable etching time. The other portion was etched according to the results of this test. After the sample had been etched and washed, it was ready for counting. This procedure was repeated several times to obtain suitable counts. The induced tracks in the sample were counted after neutron bombardment and polishing.

For counting tracks, a differential interference microscope with mesh micrometer was used after, and I made errors in calculation of the counting area. I appreciate Wagner's and Reimer's pointing out my mistakes and present a corrected Table 1 for the letter to Nature $(\mathbf{2 3 0}, 242 ; 1971)$.

Yours faithfully,

\section{S. Nishimura}

Institute of Earth Science, Kyoto University, Kyoto

Table 1 Fission Track Ages of Archaeological Materials from Japan

\begin{tabular}{|c|c|c|c|c|c|}
\hline Sample & Locality & $\begin{array}{c}\rho_{s} \\
\left(\mathrm{~cm}^{-2}\right)\end{array}$ & $\begin{array}{c}\rho_{l} \\
\left(\mathrm{~cm}^{-2}\right)\end{array}$ & $\begin{array}{c}\varphi \\
\left(\mathrm{cm}^{-2}\right)\end{array}$ & $\begin{array}{l}\text { Fission } \\
\text { track } \\
\text { age } \\
(\mathrm{yr} \mathrm{BP})\end{array}$ \\
\hline Zircon (baked earth) & Ise, Hata, Mie Pref. & $4.7 \times 10^{3}$ & $5.7 \times 10^{7}$ & $0.46 \times 10^{15}$ & 2300 \\
\hline Zircon (baked earth) & Hirakata, Osaka Pref. & $2.0 \times 10^{3}$ & $2.5 \times 10^{7}$ & $0.46 \times 10^{15}$ & 2200 \\
\hline Zircon (baked earth) & Hisai, Mie Pref. & $6.3 \times 10^{2}$ & $1.1 \times 10^{7}$ & $0.44 \times 10^{15}$ & 1500 \\
\hline Glass ball & Hirono, Uji, Kyoto Pref. & 6.3 & $4.8 \times 10^{5}$ & $2.31 \times 10^{15}$ & 1500 \\
\hline Zircon (baked earth) & $\begin{array}{l}\text { Iwasaki, Nisshin, Aichi } \\
\text { Pref. }\end{array}$ & $2.3 \times 10^{3}$ & $4.7 \times 10^{7}$ & $0.44 \times 10^{15}$ & 1300 \\
\hline “Tatara" & Ichinomiya, Okayama Pref. & 19 & $2.6 \times 10^{6}$ & $2.81 \times 10^{15}$ & 1300 \\
\hline Zircon (baked earth) & Sakai, Osaka Pref. & $2.7 \times 10^{3}$ & $6.3 \times 10^{7}$ & $0.46 \times 10^{15}$ & 1200 \\
\hline Zircon (tile) & Nagaoka, Kyoto Pref. & $\begin{array}{l}5.2 \times 10^{2} \\
5.2 \times 10^{2} \\
4.9 \times 10^{2}\end{array}$ & $\begin{array}{l}1.3 \times 10^{7} \\
1.3 \times 10^{7} \\
1.2 \times 10^{7}\end{array}$ & $\begin{array}{l}0.50 \times 10^{15} \\
0.50 \times 10^{15} \\
0.50 \times 10^{15}\end{array}$ & $\begin{array}{l}1200 \\
1200 \\
1150\end{array}$ \\
\hline Zircon (pottery) & Nagaoka, Kyotó Pref. & $4.3 \times 10^{2}$ & $1.1 \times 10^{7}$ & $0.50 \times 10^{15}$ & 1150 \\
\hline "Tatara" & $\begin{array}{l}\text { Habutenno, Wake, } \\
\text { Okayama Pref. }\end{array}$ & 14 & $1.1 \times 10^{6}$ & $1.47 \times 10^{15}$ & 1150 \\
\hline $\begin{array}{l}\text { Zircon (opening of } \\
\text { folge) }\end{array}$ & $\begin{array}{l}\text { Arai, Fukaya, Siraishi } \\
\text { City }\end{array}$ & $4.3 \times 10^{2}$ & $1.1 \times 10^{7}$ & $0.50 \times 10^{15}$ & 1150 \\
\hline "Tatara" & $\begin{array}{l}\text { Michikunihara, Fukaya, } \\
\text { Shiraishi City }\end{array}$ & $\begin{array}{l}14 \\
13 \\
13\end{array}$ & $\begin{array}{l}2.1 \times 10^{6} \\
2.1 \times 10^{6} \\
2.1 \times 10^{6}\end{array}$ & $\begin{array}{l}2.81 \times 10^{15} \\
2.80 \times 10^{15} \\
2.82 \times 10^{15}\end{array}$ & $\begin{array}{l}1150 \\
1050 \\
1050\end{array}$ \\
\hline "Tatara" & $\begin{array}{l}\text { Habutenno, Wake, } \\
\text { Okayama Pref. }\end{array}$ & $\begin{array}{c}9.3 \\
10 \\
9.4\end{array}$ & $\begin{array}{l}1.5 \times 10^{6} \\
1.5 \times 10^{6} \\
1.5 \times 10^{6}\end{array}$ & $\begin{array}{l}2.81 \times 10^{15} \\
2.80 \times 10^{15} \\
2.82 \times 10^{15}\end{array}$ & $\begin{array}{l}1050 \\
1150 \\
1100\end{array}$ \\
\hline "Tatara" & $\begin{array}{l}\text { Odatemori, Ajigazawa, } \\
\text { Aomori Pref. }\end{array}$ & 7.8 & $9.8 \times 10^{5}$ & $2.82 \times 10^{15}$ & 700 \\
\hline Zircon (baked earth) & Fuso, Aichi Pref. & $1.4 \times 10^{3}$ & $5.5 \times 10^{7}$ & $0.44 \times 10^{15}$ & 700 \\
\hline Glaze on bowl & Isumi, Toki City & 0.45 & $1.1 \times 10^{5}$ & $1.9 \times 10^{15}$ & 400 \\
\hline
\end{tabular}

